\title{
Regional-specific activation of phagocytosis in the rat brain in the conditions of sepsis-associated encephalopathy
}

\author{
T. V. Shulyatnikova ${ }^{A, B, C, D}$, V. O. Shavrin ${ }^{A, E, F}$
}

Zaporizhzhia State Medical University, Ukraine

A - research concept and design; B - collection and/or assembly of data; C - data analysis and interpretation; D - writing the article;

$\mathrm{E}$ - critical revision of the article; $\mathrm{F}$ - final approval of the article

In the condition of sepsis-associated encephalopathy (SAE), the brain neuroinflammatory response is considered as one of the most critical mechanisms of tissue damage and impaired cerebral homeostasis. The main cell population of the brain responsible for the immune surveillance is microglia, and its phagocytic activity is a fundamental function providing both homeostatic and damaging properties.

The aim of this study was to determine the immunohistochemical and ultrastructural specificity of the phagocytosis activation in different rat brain regions in the conditions of experimental sepsis.

Materials and methods. The study was conducted in Wistar rats: 5 sham-operated animals and 20 rats with cecum ligation and puncture (CLP). The immunohistochemical study of CD68 expression in the cortex, white matter, hippocampus, thalamus, caudate/putamen was carried out in the period of $20-48 \mathrm{~h}$ postoperatively. The cerebral cortex was examined using transmission electron microscopy.

Results. Beginning from the $20^{\text {th }} \mathrm{h}$ after CLP, there was a significant dynamic increase in the values of the relative area of CD68 expression, the number of immunopositive cells, as well as the percentage of immunopositive cells with amoeboid morphology in all animals of the CLP group, with a predominance of the indicators in the lethal group of rats. The highest levels of phagocytic activity were noted in the white matter and caudate/putamen in both the survived and non-survived animals. Ultrastructurally, the microgliocytes of the lethal group were characterized by signs of actively phagocytic cells and extensive glial-neuronal interaction; phagocytosing microglia in the survived animals showed an active involvement in the processes of necrotic debris elimination into the vasculature.

Conclusions. In the conditions of SAE, there is the early and dynamic increase in phagocytosis activation with the predominant localization in the brain white matter and caudate/putamen, which could conceivably indicate a special role of these brain areas in the mechanisms of neuroinflammatory response in the conditions of systemic inflammation. In the brain of non-survived animals, the phagocytosis indices are higher than in the group of survivors, which most likely indicates a natural response of microglia to more pronounced destructive processes, but it does not preclude a concurrent neurotoxic activity of CD68-positive cells on the surrounding tissue elements.

\section{Регіональні особливості активації фагоцитозу в мозку щурів в умовах сепсис-асоційованої енцефалопатії}

\section{Т. В. Шулятнікова, В. О. Шаврін}

В умовах сепсис-асоційованої енцефалопатії (CAЕ) внутрішньомозкову нейрозапальну відповідь вважають одним із головних механізмів тканинного пошкодження та порушення мозкового гомеостазу. Основна клітинна популяція мозку, що відповідає за імунну відповідь, - мікроглія, а ії фагоцитарна активність - основна функція, яка забезпечує її гомеостатичні та пошкоджувальні властивості.

Мета роботи - визначити імуногістохімічні й ультраструктурні особливості активації фрагоцитозу в різних відділах мозку щурів в умовах експериментального сепсису.

Матеріали та методи. Дослідження виконали на щурах лінії Вістар: 5 хибнооперованих тварин і 20 щурів із перев'язкою та пункцією сліпої кишки (CLP). Здійснили імуногістохімічне дослідження експресії маркера CD68 у корі, білій речовині, гіпокампі, таламусі, хвостатому ядрі/путамені в термін 20-48 годин післяопераційного періоду. За допомогою трансмісійної електронної мікроскопії дослідили кору великих півкуль.

Результати. У термін від 20 годин післяопераційного періоду спостерігали істотне динамічне підвищення значень відносної площі експресії CD68, кількості імунопозитивних клітин, а також відсотка імунопозитивних клітин з амебоїдною морфологією в усіх тварин CLP групи з переважанням показників у щурів летальної групи. Найвищі показники активності фагоцитозу визначили в білій речовині та хвостатому ядрі/путамені у групі й померлих тварин, і тих, які вижили. Ультраструктурно для мікрогліоцитів померлих тварин характерні ознаки клітин, що активно фагоцитують, і поширеної гліо-нейрональної взаємодії; у тварин, які вижили, фагоцитуюча мікроглія показала активну участь у процесах елімінації некротичного детриту в судинне русло.

Висновки. В умовах САЕ в паренхімі мозку відбувається раннє та динамічне зростання фагоцитарної активності клітин із переважанням процесу в білій речовині та хвостатому ядрі/путамені. Теоретично це може вказувати на особливу роль цих ділянок мозку в механізмах нейрозапальної відповіді в умовах системного запалення. У мозку тварин, які померли, показники фагоцитозу мають вищі значення порівняно з тваринами, які вижили. Найімовірніше, це свідчить про закономірну реакцію мікроглії на вираженіші процеси деструкції, але не виключає одночасний нейротоксичний вплив CD68-позитивних клітин на навколишню нервову тканину.
Key words: sepsis-associated encephalopathy, phagocytosis, microglia, CD68, transmission microscopy election.

\section{Zaporozhye} medical journal 2021; 23 (1), 111-119

*E-mail: shulyatnikova.tv@gmail. com

Киючові слова: сепсис-асоційована енцефалопатія, фагоцитоз, мікроглія, CD68, просвічуюча електронна мікроскопія. 
Ключевые слова: сепсисассоциированная энцефалопатия, фагоцитоз, микроглия, $\mathrm{CD} 68$, просвечивающая электронная микроскопия.

Запорожский медицинский журнал. 2021. T. 23, № 1(124) C. 111-119

\title{
Региональные особенности активации фагоцитоза в мозге крыс в условиях сепсис-ассоциированной энцефалопатии
}

\author{
Т. В. Шулятникова, В. А. Шаврин
}

В условиях сепсис-ассоциированной энцефралопатии (САЭ) внутримозговой нейровоспалительный ответ считают одним из главенствующих механизмов тканевого повреждения и нарушения мозгового гомеостаза. Основная клеточная популяция мозга, отвечающая за иммунный ответ, - микроглия, а ее фагоцитарная активность является основополагающей функцией, обеспечивающей ее и гомеостатические, и повреждающие свойства.

Цель работы - определение иммуногистохимических и ультраструктурных особенностей активации фагоцитоза в разных областях головного мозга крыс в условиях экспериментального сепсиса.

Материалы и методы. Исследование проведено на крысах линии Вистар: 5 ложнооперированных животных и 20 крыс с перевязкой и пункцией слепой кишки (CLP). Проведено иммуногистохимическое исследование экспрессии маркера CD68 в коре, белом веществе, гиппокампе, таламусе, хвостатом ядре/скорлупе в срок 20-48 ч послеоперационного периода. C помощью трансмиссионной электронной микроскопии исследована кора больших полушарий.

Результаты. В срок после 20 часов послеоперационного периода отмечают существенное динамическое повышение значений относительной площади экспрессии CD68, количества иммунопозитивных клеток, а также процента иммунопозитивных клеток с амебоидной морфологией у всех животных CLP группы с преобладанием показателей у крыс летальной группы. Наиболее высокие показатели активности фагоцитоза отмечены в белом веществе и хвостатом ядре/скорлупе в группе и умерших, и выживших животных. Ультраструктурно для микроглиоцитов группы умерших животных характерны признаки активно фагоцитирующих клеток и распространенное глио-нейрональное взаимодействие; у выживших животных фагоцитирующая микроглия показала активное участие в процессах элиминации некротического детрита в сосудистое русло.

Выводы. В условиях САЭ в мозге отмечено раннее и динамическое нарастание признаков активации фагоцитоза с преимущественной локализацией в белом веществе и хвостатом ядре/скорлупе. Предположительно, это может указывать на особую роль этих областей мозга в механизмах нейровоспалительного ответа в условиях системного воспаления. В мозге умерших животных показатели фагоцитоза имеют более высокие значения по сравнению с группой выживших. Скорее всего, это свидетельствует о закономерной реакции микроглии на более выраженные процессы деструкции, но не исключает одновременное нейротоксическое воздействие CD68-позитивных клеток на окружающую нервную ткань.

Sepsis-associated encephalopathy (SAE) being one of the most common complication of sepsis, clinically manifests from the delirium to coma, thus directly determines the survival rate of critically ill patients [1,2]. The mechanisms of SAE development remain to be elucidated, but the important role of brain immunity activation was emphasized. In this regard, microglia, the resident brain macrophages, are considered to play a crucial role in triggering neuroinflammatory responses. In healthy brain, resting microglia provide a neuroprotective environment and contribute substantially to neurogenesis, neuronal differentiation, elimination of excessive and apoptotic neurons, neuronal migration, axon growth, synaptogenesis, astrocytogenesis, oligodendrocytogenesis and angiogenesis $[3,4]$. However, being a highly important connecting link in the homeostatic balance of the central nervous system, in numerous cases such as sepsis, microglia move towards the neurotoxic phenotype and support uncontrolled neuroinflammation [5]. In the conditions of systemic inflammatory challenge, neuroinflammation is considered as one of the major damaging factors inside the brain medium [6]. The animal studies examining microglial activation after a single systemic challenge with live bacteria or lipopolysaccharide show a more rapid and profound glial reactivity to the latter factor, accompanied by acute pro-inflammatory environment in the brain tissue [7]. Still, the results of these studies remain rather ambiguous and do not give clear consecutive mechanisms of the initiation and development of neuroinflammatory response to systemic inflammatory challenge. The contribution of microglia to restoring the brain tissue, damaged by endogenous toxins, also remains unclear. In this regard, considering the problem of SAE, it would be logical to apply the common animal sepsis model reliably simulating natural, multifactorial state of systemic infection.
In the conditions of severe sepsis, it seems principal to determine the degree of microglial activation in different brain areas, thus evaluating region-specific features of microglial reactivity and the neuroinflammatory response severity depending on the various brain structures.

\section{Aim}

To determine the immunohistochemical and ultrastructural specificity of the phagocytosis activation in different rat brain regions in the conditions of cecum ligation and puncture sepsis model.

\section{Materials and methods}

The study was conducted in male Wistar rats, weighing 200-300 g ("Biomodelservice", Kyiv, Ukraine). The animals were kept in acrylic cages under standard conditions: at a 12-h light-dark cycle, at $22 \pm 2{ }^{\circ} \mathrm{C}$, with free access to food (standard chow for rats, "Biomodelservice", Kyiv, Ukraine) and water. All procedures were performed in accordance with the European Convention for the Protection of Vertebrate Animals Used for Experimental and other Scientific Purposes (Strasbourg, 18 March 1986; ETS No. 123) and the Directive 2010/63/EU on the protection of animals used for scientific purposes.

The animals were subjected to the cecal ligation and puncture (CLP) model of sepsis, the most widely used to induce polymicrobial abdominal sepsis in rodents. Animals were randomly divided into 2 groups: an experimental CLP group ( $\mathrm{n}=20$ ) and a control group (sham-operated rats, $n=5$ ). The consecutive CLP-procedure stages were performed as described by our previous study [8]. Within 
the first $2 \mathrm{~h}$ postoperatively, the animals were observed every $30 \mathrm{~min}$, then - every $6 \mathrm{~h}$ up to $48 \mathrm{~h}$ after the CLP procedure. The following signs were evaluated: lethargy, diarrhoea, fever/hypothermia, piloerection, periorbital exudation, respiratory disorders, social isolation, huddling and malaise. Within a 20-38-h period after the operation, in the CLP group, 9 rats showed severe clinical signs of sepsis and were euthanized (subgroup "CLP-B" - lethal), 11 animals survived until the end of the experiment (subgroup "CLP-A" - survived). In the control animals (subgroup "CLP-C"), there were no lethal cases. All the survived and control animals were euthanized $48 \mathrm{~h}$ after the operation by intraperitoneal administration of sodium thiopental solution (60 mg/kg).

Coronal sections of the brain hemispheres were fixed in $10 \%$ buffered formalin and after standard processing steps, the material was embedded in paraffin blocks. Histopathological analysis of samples was evaluated in sections stained with hematoxylin and eosin. Immunohistochemical (IHC) study was carried out according to the standard protocol provided by the antibody manufacturer. The mouse monoclonal anti-CD68 primary antibody (clone PG-M1, RTU, Dako, Denmark) and Ultra VisionQuanto Detection imaging system with diaminobenzidine (Thermo Scientific Inc., USA) were used. The results of $\mathrm{IHC}$ reaction were assessed at $\times 200$ magnification in a standardized field of view (SFV) of the microscope Scope. A1 "Carl Zeiss" (Germany) using Jenoptik Progres Gryphax 60N-C1"1,0x426114 (Germany) camera and the program Videotest-Morphology 5.2.0.158 (VideoTest LLC, Russia). The expression of CD68 was assessed as a percentage of the relative area (S rel, \%) of immunolabeling to the total area of the section in the microscope SFV. CD68 ${ }^{+}$expression related to vessel walls (endothelial and perivascular expressing macrophages) was ignored, as not being the object of our interest. In addition to the relative area of the marker expression, the number of $\mathrm{CD}^{2} 8^{+}$cells in the SFV, as well as the percentage of $\mathrm{CD} 68^{+}$ cells with amoeboid morphology, were assessed. Such cells were presented as more rounded, with shortened, thickened processes and slightly more abundant cytoplasm in comparison with elongated, rod-shaped and ramified resting forms (the insets in the Fig. 6, 8, 10, 12).

For the comparative statistical analysis of the specified criteria, such brain regions as cortex, subcortical white matter, hippocampus, thalamus and caudate nucleus/putamen were selected. Five SFV of each specified region were analyzed for each animal.

Data were analyzed using the package of Statistica ${ }^{\circledR}$ for Windows 13.0 (StatSoft Inc., license No. JPZ804I382130ARCN10-J). The median (Me), the lower and upper quartiles (Q1; Q3) were calculated; the comparison between two groups of observations was carried out using the Mann-Whitney U-test, between three or more groups of observations - using the Kruskal-Wallis test. The results were considered statistically significant at $95 \%(P<0.05)$.

For transmission electron microscopy (TEM) study, the brains were removed in 1-5 min after stopping the heartbeat and placed in a standard fixation solution for TEM: $2.5 \%$ glutaraldehyde (Alfa Aesar by Thermo Fisher Scientific) in 0,1 M phosphate buffer (PB), pH = 7.4. Blocks up to $1 \times 1 \times 1 \mathrm{~mm}$ were cut from the sensorimotor cortex of the frontal lobe of the left hemisphere and placed for $2 \mathrm{~h}$ (at $\mathrm{t}=4^{\circ} \mathrm{C}$ ) in the same fixation solution with the addition of sucrose. Additional fixation for $2 \mathrm{~h}$ was performed using $1 \%$ osmium tetroxide on PB. Specimens were next processed through graded (up to $100 \%$ ) series of ethanol for dehydration and contrasted with a $2.5 \%$ uranyl acetate solution for $2 \mathrm{~h}$. Dehydrated specimens were then infiltrated with a mixture of acetone and Epon resin $(2: 1 ; 1: 1 ; 1: 2)$, embedded in epoxy medium Epon-812 (Sigma-Aldrich Chemie $\mathrm{GmbH}$, Taufkirchen, Germany, 45345) and polymerized in two steps: at $36{ }^{\circ} \mathrm{C}(12 \mathrm{~h}) ; 56{ }^{\circ} \mathrm{C}(24 \mathrm{~h})$. Semithin (1-2 $\left.\mu \mathrm{m}\right)$ and ultrathin (55-65 nm) sections were cut using an ultramicrotome (PowerTome RMC Boeckeler, USA) and stained with lead citrate according to Reynolds (30 min, $\mathrm{t}=25^{\circ} \mathrm{C}$ ). Semithin sections were stained with methylene blue and basic fuchsin. Examination of ultrathin sections at different magnifications and imaging were performed using the PEM-100-01 electron microscope ("Selmi", Sumy, Ukraine) at $65 \mathrm{kV}$.

\section{Results}

The immunohistochemical study in control animals showed a rather low level of the CD68 protein expression in brain cells for all the studied parameters and its unequal expression in different brain regions.

Thus, at $48 \mathrm{~h}$ of the experiment, the sham-operated rats showed the highest indicators of the CD68 expression relative area and the number of immunopositive cells in the subcortical white matter, respectively: $0.21(0.20$; $0.22) \% ; 8.00(7.00 ; 11.00)$. In addition, this area was characterized by the highest percentage of immunopositive cells, in comparison to other areas, with changed morphology towards the amoeboid form, which was equal to 5.00 (2.00; $10.00) \%$. Less pronounced indicators were identified in the cortex, hippocampus, thalamus and caudate/putamen. In these areas, S rel. (\%) and the number (units) of $\mathrm{CD}^{+} 8^{+}$ cells were: in the cortex $-0.13(0.11 ; 0.14) \%, 6.00(3.00$; $7.00)$; in the hippocampus - $0.13(0.12 ; 0.14) \%, 6.00$ $(4.00 ; 8.00)$; in the thalamus $-0.09(0.07 ; 0.10) \%, 4.00$ $(3.00 ; 6.00)$; in the caudate/putamen $-0.11(0.10 ; 0.12) \%$, $5.00(3.00 ; 9.00)$. The percentage of $\mathrm{CD} 8^{+}$cells with amoeboid morphology in these areas was minimal (Table 1).

In the survived group of animals (CLP-A), in relation to the control group, a moderate increase in parameters of phagocytic activity in the brain tissue was found by $48 \mathrm{~h}$ of the experiment, also showing regional heterogeneity. Among all the regions studied, the highest indicators of the S rel. (\%) of CD68 expression and the number of immunopositive cells were typical for the subcortical white matter; there was also a significant increase in the number of immunopositive cells with amoeboid morphology. Among the studied areas, statistically significant differences in the indicators of $\mathrm{S}$ rel. and the number of $\mathrm{CD}^{+} 8^{+}$cells, in comparison to the control, were characteristic for: cortex, subcortical white matter, hippocampus, and caudate/ putamen (Table 1).

In the non-survived animal group (CLP-B), the most significant increase in all the studied parameters was observed, which was also characterized by regional differences. The highest values of the $S$ rel. of $\mathrm{CD} 68^{+}$expression, the number of immunopositive cells and cells with amoeboid morphology were noted in (in descending order): subcortical 


\section{Оригинальные исследования}

Table 1. The indicators of phagocytosis activation in different brain regions in animals of different experimental groups. Data are presented as median (Me) with lower and upper quartiles (Q1; Q3)

\begin{tabular}{|c|c|c|c|c|c|c|c|c|}
\hline \multicolumn{3}{|l|}{ CLP-A } & \multicolumn{3}{|l|}{ CLP-B } & \multicolumn{3}{|l|}{ CLP-C } \\
\hline $\begin{array}{l}\text { S rel. (\%) } \\
\text { in SFV }\end{array}$ & $\begin{array}{l}\text { CD68 }{ }^{+} \text {cells } \\
\text { number in SFV }\end{array}$ & $\begin{array}{l}\% \text { of CD68+ cells } \\
\text { in SFV } \\
\text { with amoeboid } \\
\text { morphology }\end{array}$ & \begin{tabular}{|l|}
$\mathrm{S}$ rel. $(\%)$ \\
in SFV
\end{tabular} & $\begin{array}{l}\text { CD68 } 8^{+} \text {cells } \\
\text { number in SFV }\end{array}$ & $\begin{array}{l}\% \text { of CD68 } \\
\text { in SFV } \\
\text { with amoeboils } \\
\text { morphology }\end{array}$ & $\begin{array}{l}\text { S rel. (\%) } \\
\text { in SFV }\end{array}$ & $\begin{array}{l}\text { CD68 }{ }^{+} \text {cells } \\
\text { number in SFV }\end{array}$ & $\begin{array}{l}\% \text { of CD68 }{ }^{+} \text {cells } \\
\text { in SFV } \\
\text { with amoeboid } \\
\text { morphology }\end{array}$ \\
\hline \multicolumn{9}{|l|}{ Cortex } \\
\hline $0.30(0.29 ; 0.32)^{*}$ & $7.00(6.00 ; 8.00)^{*}$ & $4.00(2.00 ; 7.00)$ & $0.76(0.65 ; 0.73)^{*}$ & $11.00(10.00 ; 14.00)^{*}$ & $22.00(9.00 ; 23.00)^{*}$ & $0.13(0.11 ; 0.14)$ & $6.00(3.00 ; 7.00)$ & $2.00(1.00 ; 6.00)$ \\
\hline \multicolumn{9}{|c|}{ Subcortical white matter } \\
\hline $0.47(0.40 ; 0,48)^{*}$ & $11.00(8.00 ; 12.00)^{*}$ & $10.00(6.00 ; 19.00)^{*}$ & $0.95(0.92 ; 1.15)^{*}$ & $15.00(12.00 ; 16.00)^{*}$ & $30.00(25.00 ; 35.00)^{*}$ & $0.21(0.20 ; 0.22)$ & $8.00(7.00 ; 11.00)$ & $5.00(2.00 ; 10.00)$ \\
\hline \multicolumn{9}{|l|}{ Hippocampus } \\
\hline $0.34(0.32 ; 0.35)^{*}$ & $8.00(7.00 ; 9.00)^{*}$ & $4.00(3.00 ; 8.00)$ & $0.86(0.74 ; 0.88)^{*}$ & $12.00(11.00 ; 13.00)^{*}$ & $19.00(10.00 ; 20.00)^{\star}$ & $0.13(0.12 ; 0.14)$ & $6.00(4.00 ; 8.00)$ & $3.00(1.00 ; 9.00)$ \\
\hline \multicolumn{9}{|l|}{ Thalamus } \\
\hline $0.10(0.09 ; 0.20)$ & $5.00(2.00 ; 7.00)$ & $1.00(0.00 ; 4.00)$ & $0.18(0.09 ; 0.21)$ & $5.00(3.00 ; 7.00)$ & $2.00(0.00 ; 4.00)$ & $0.09(0.07 ; 0.10)$ & $4.00(3.00 ; 6.00)$ & $1.00(0.00 ; 3.00)$ \\
\hline \multicolumn{9}{|l|}{ Caudate/putamen } \\
\hline $0.25(0.21 ; 0.35)^{*}$ & $6.00(4.00 ; 10.00)^{*}$ & $3.00(1.00 ; 6.00)$ & $0.97(0.96 ; 1.04)^{*}$ & $14.00(12.00 ; 15.00)^{*}$ & $29.00(19.00 ; 32.00)^{\star}$ & $0.11(0.10 ; 0.12)$ & $5.00(3.00 ; 9.00)$ & $2.00(0.00 ; 3.00)$ \\
\hline
\end{tabular}

*: significant differences in indicators of the same brain region compared to the control animals $(P<0.05)$; CLP-A: survived group; CLP-B: lethal group; CLP-C: control group.

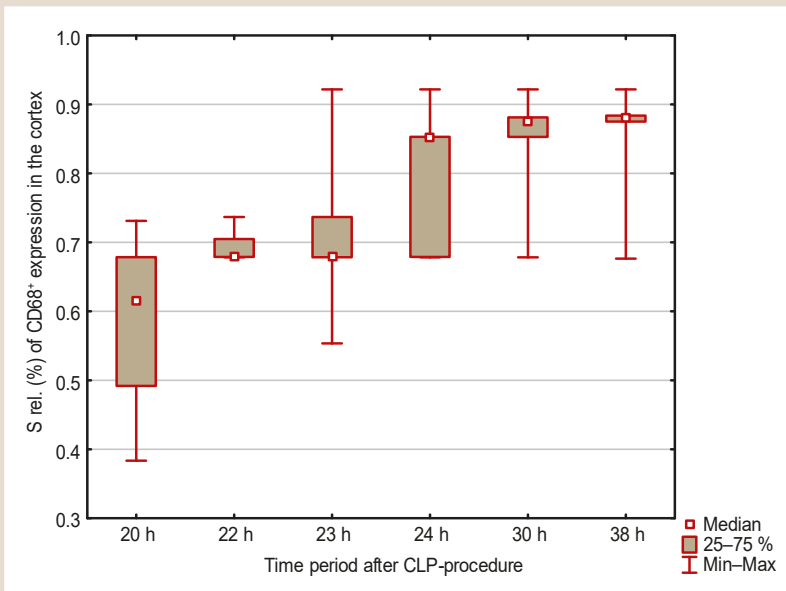

Fig. 1. Dynamics of the relative area of CD68+ expression (in the microscope SFV, \%) in the cerebral cortex of CLP-B rats in the postoperative period.

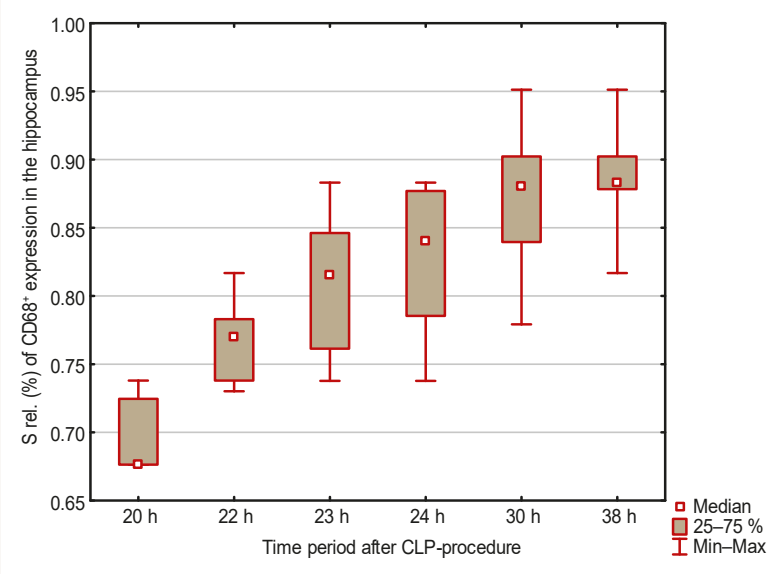

Fig. 3. Dynamics of the relative area of CD68+ expression (in the microscope SFV, \%) in the hippocampus of CLP-B rats in the postoperative period.

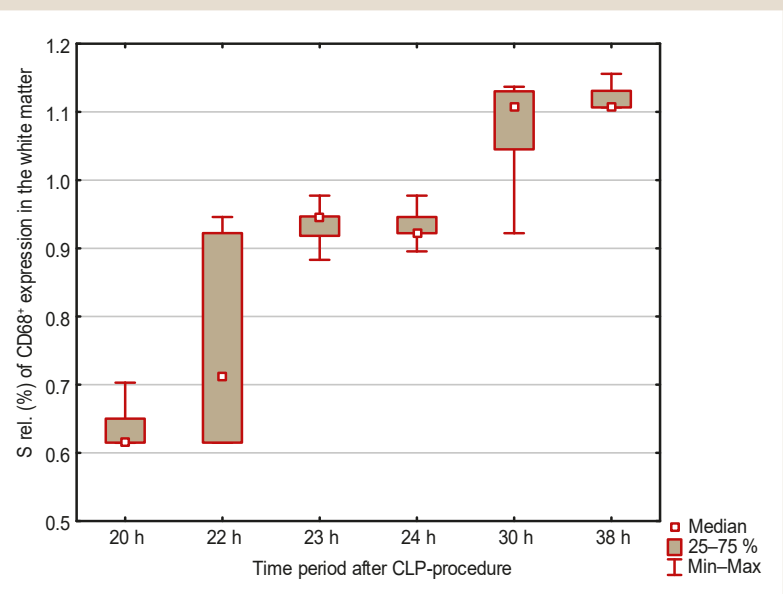

Fig. 2. Dynamics of the relative area of CD68+ expression (in the microscope SFV, \%) in the subcortical white matter of CLP-B rats in the postoperative period.

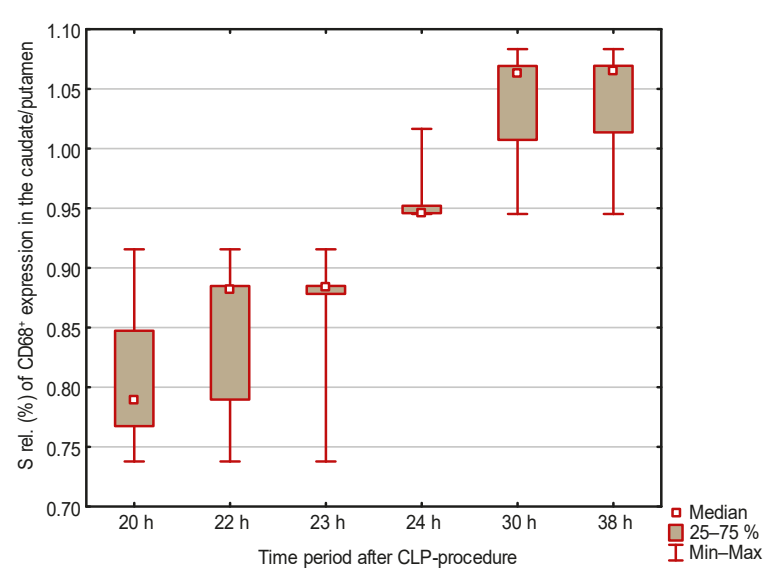

Fig. 4. Dynamics of the relative area of CD68+ expression (in the microscope SFV, \%) in the caudate/putamen of CLP-B rats in the postoperative period. white matter, caudate/putamen, hippocampus and cortex. All the values were statistically significantly different from the control ones $(P<0.05)$. In the thalamus area, as in the CLP-A group, an increase in indicators was not statistically significant, in relation to the control (Table 1).
Thus, summarizing the data obtained from all animals of each group (CLP-A, CLP-B, CLP-C), the highest $S$ rel. indicators of the $\mathrm{CD} 68^{+}$expression, as well as the number of immunopositive cells and cells with changing morphology towards phagocytic forms, were typical for the non-survived 


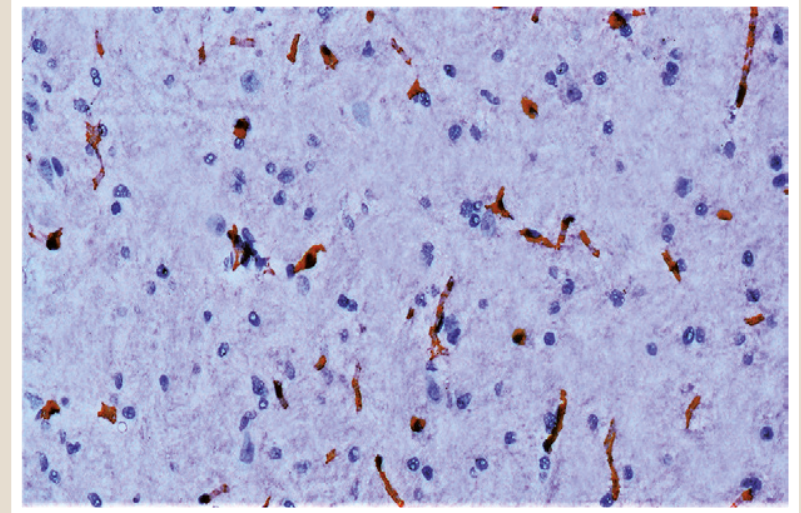

Fig. 5. CD68 expression in the cortex of the non-survived rat (CLP-B group) $20 \mathrm{~h}$ after the CLP procedure. (anti-CD68, Dako, Denmark). $\times 200$.

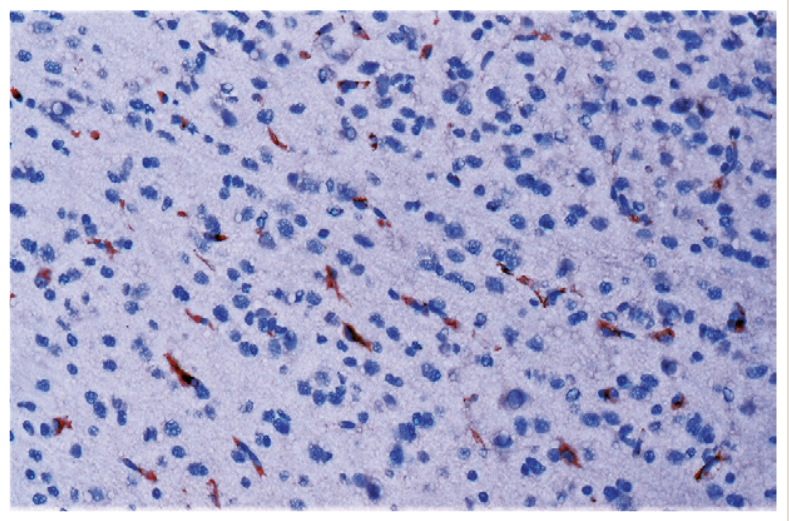

Fig. 7. CD68 expression in the white matter of the non-survived rat (CLP-B group) $20 \mathrm{~h}$ after the CLP procedure. (anti-CD68, Dako, Denmark). $\times 200$.

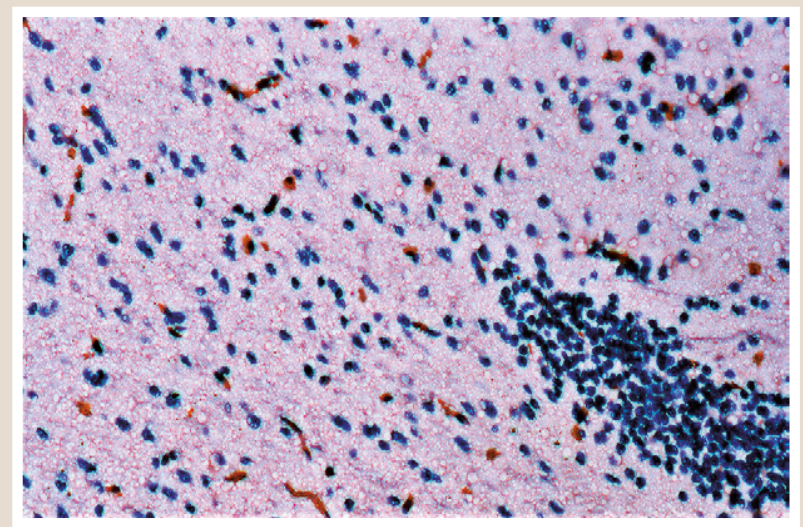

Fig. 9. CD68 expression in the hippocampus of the non-survived rat (CLP-B group) $20 \mathrm{~h}$ after the CLP procedure. (anti-CD68, Dako, Denmark). $\times 200$.

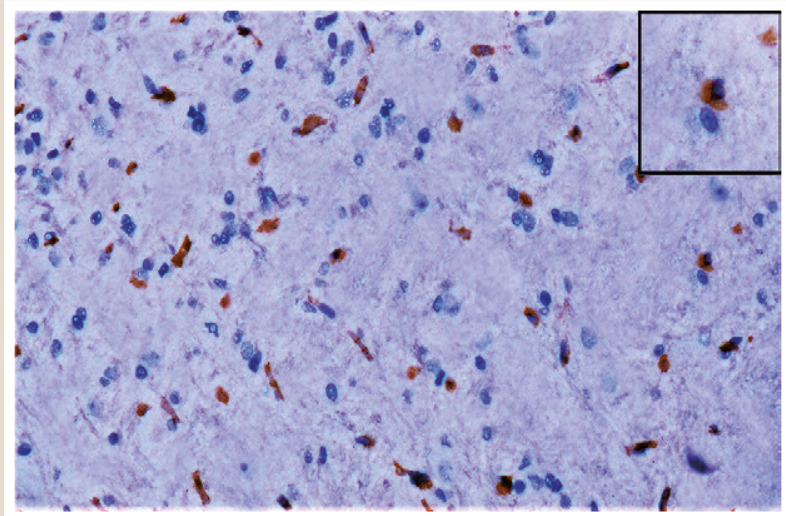

Fig. 6. CD68 expression in the cortex of the non-survived rat (CLP-B group) $38 \mathrm{~h}$ after the CLP procedure. The inset shows the magnified image of an amoeboid cell. (antiCD68, Dako, Denmark). $\times 200$.

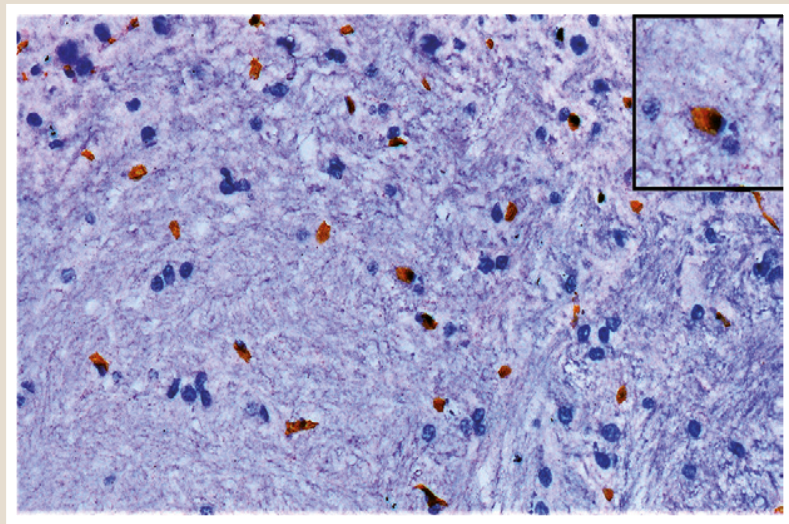

Fig. 8. CD68 expression in the white matter of the non-survived rat (CLP-B group) $38 \mathrm{~h}$ after the CLP procedure. The inset shows the magnified image of an amoeboid cell. (anti-CD68, Dako, Denmark). $\times 200$.

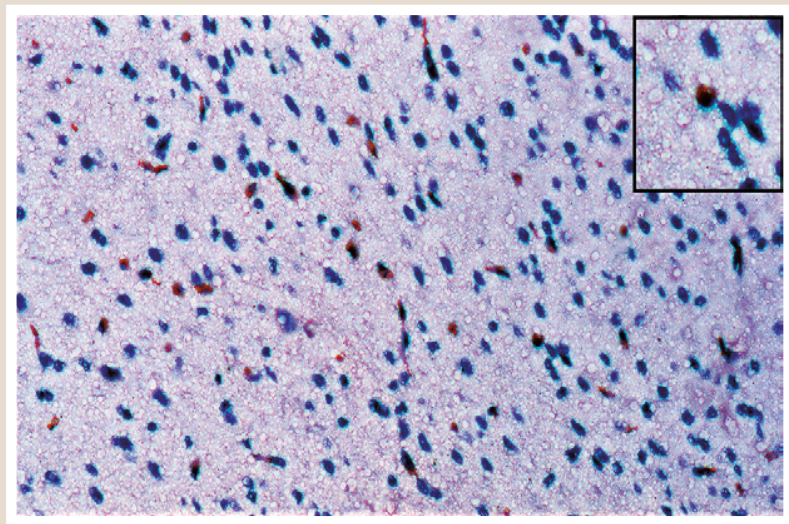

Fig. 10. CD68 expression in the hippocampus of the non-survived rat (CLP-B group) $38 \mathrm{~h}$ after the CLP procedure. The inset shows the magnified image of an amoeboid cell. (anti-CD68, Dako, Denmark). $\times 200$. animal group (CLP-B), and all the differences were significant as compared to the control values.

Depending on the time point of the postoperative period, when decompensation of the animal state of CLP-B group occurred and euthanasia was performed, the indicators of phagocytosis activation also had unique features. Thus, the maximum increase in the $\mathrm{S}$ rel. of $\mathrm{CD}^{+} 8^{+}$expression was observed $38 \mathrm{~h}$ after the CLP-procedure in all the studied areas other than the thalamic, where this increase was not statistically significant (Fig. 1-12).

Substantial changes in the cortical microgliocyte ultrastructure were observed in the CLP-B group beginning $20 \mathrm{~h}$ after the CLP-procedure. In the dynamics of the postoperative period, microglia gradually acquired morphological signs of active phagocytic cells with the maximum manifestations at the $38^{\text {th }}$ observational hour. 


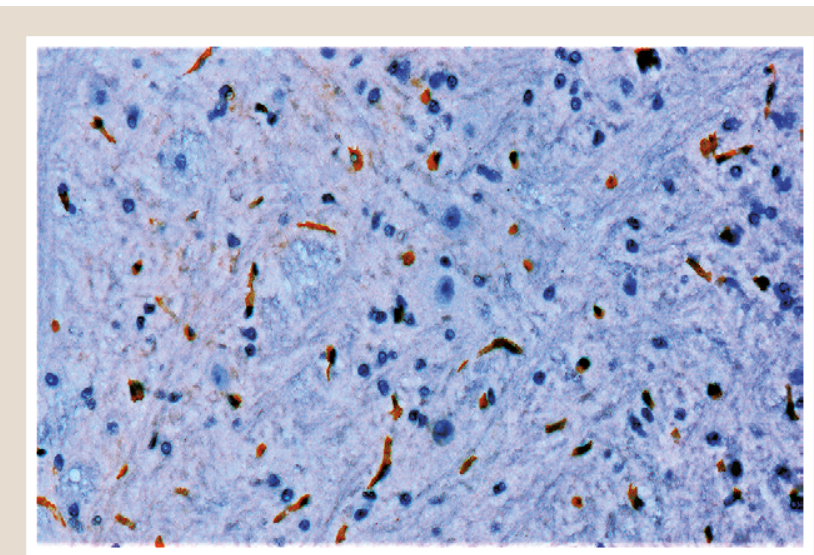

Fig. 11. CD68 expression in the caudate/putamen of the non-survived rat (CLP-B group) $20 \mathrm{~h}$ after the CLP procedure. (anti-CD68, Dako, Denmark). $\times 200$.

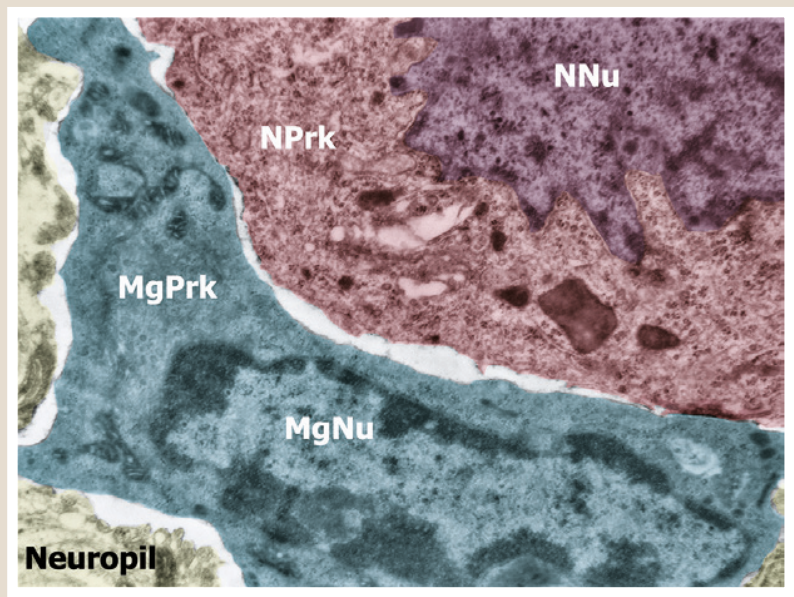

Fig. 13. Microglial (dark-blue-colored) location close to the neuron (brown-red-colored) signed by ischemic condensation, homogenization, and formation of the tight connection with microglial cell. Delated spaces (highly e-translucent) between the microgliocyte plasma membrane and surrounding neuropil (yellow-colored). The cortex of a nonsurvived rat (CLP-B group). $20 \mathrm{~h}$ after the CLP-procedure. TEM, mag. $\times 14,000$.

NNu: neuronal nucleus (dark-violet-colored); NPrk: neuronal perikaryon; MgNu: microglial nucleus; MgPrk: microglial perikaryon.

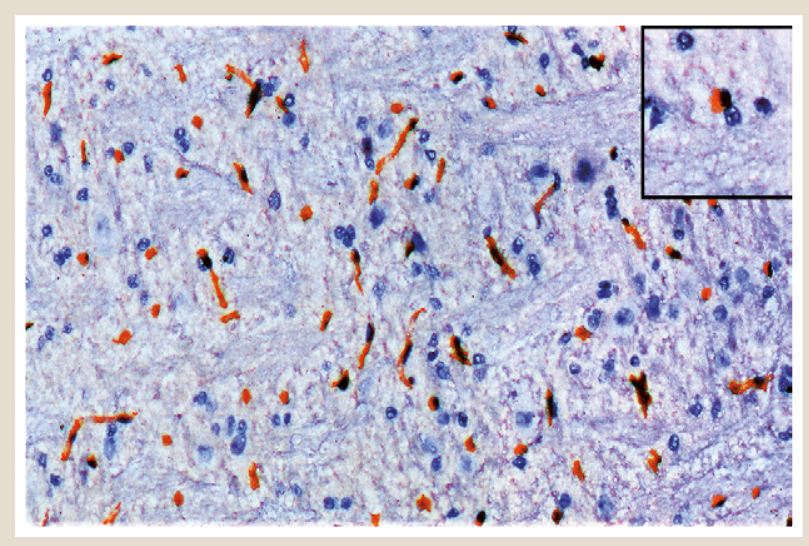

Fig. 12. CD68 expression in the caudate/putamen of the non-survived rat (CLP-B group) $38 \mathrm{~h}$ after the CLP procedure. The inset shows the magnified image of an amoeboid cell. (anti-CD68, Dako, Denmark). ×200.

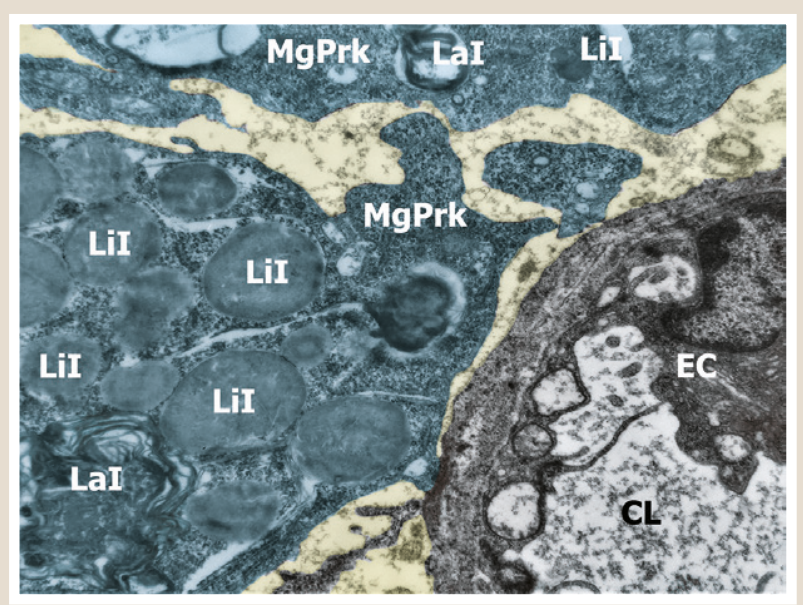

Fig. 14. Close approximation of two microglial cells to the capillary wall and the formation by one of them of the tight connection with the vascular outer layer. Accumulation of a number of lipid and complex lamellar inclusions in the microglial cytoplasm. Enlarged intercellular spaces (yellow-colored) around microgliocytes. The cortex of a survived rat (CLP-A group). $48 \mathrm{~h}$ after the CLP-procedure. TEM, mag. $\times 12,000$.

MgPrk: microglial perikaryon; Lil: lipid inclusions; Lal: lamellar inclusions; EC: endothelial cell; CL: capillary lumen.
It was accompanied by an increase in the perikaryon volume and thickening of the microglial processes due to the accumulation of a large number of lipid and complex lamellar inclusions, lipofuscin granules and residual bodies in them (Fig. 14). The immunohistochemical study using the light microscopy revealed an amoeboid shape of such cells. Microglial plasma membranes displayed loss of contacts with the surrounding structures, resulting in the appearance of extended intercellular spaces around and indicating an increase in their mobility and migration activity. Most often, such microgliocytes were found in close connection with ischemically affected neurons, undergoing the formation of close contacts with their cell membranes and apparently turning into their satellites (Fig. 13).

In the group of survived animals (CLP-A), at $48 \mathrm{~h}$ of the postoperative period, the relative frequency of active phagocytic microgliocytes in the cortical sections was slightly lower than that in the lethal group at $38 \mathrm{~h}$-time point, but they had the same ultrastructural distinctive features. In the survived animals, the accumulation of such phagocytes around and in close connection with the walls of venules and capillaries was seen, where microglia often formed tight contacts with the blood-brain barrier structures (Fig. 14).

\section{Discussion}

In the field of neuroglial physiology, one of the most acute problems is the origin, typical heterogeneity, and cellular reactivity of microglia. All of these issues still do not have clear answers and have been only marginally covered, remaining a subject of study for many decades. The latest studies in this area show the theoretical possibility of the heterogeneous origin of different types of microglia, as well as their differentiated response to various pathological effects in different regions of the brain $[9,10]$.

Microglial pro-inflammatory M1-like/anti-inflammatory M2-like polarization is also an actively controversial issue, leaving many white spots in the concept of the multidirectional effect of microglia on the surrounding tissue structures. Currently, this subdivision is already considered rather 
simplified and one that does not reflect the real, substantially situational, context-dependent and region-dependent variety of microglial reactions to the impact of any factors [9]. However, this classification still exists and is actively used in the interpretation of one or another effect of microgliocytes on the nervous tissue state. During sepsis, it is supposed that microglia could induce both neurotoxic and repairing effect on the tissue depending on the microglial phenotype assumed [5].

Until now, there is no uniform definition of the "microglial activation". This concept potentially includes a number of genetic, molecular, morphological and functional changes in cells, and is determined by research methods and models of exposure to them. In the most cases, the researchers themselves specify the individual signs of "microglia activation" in a particular study. "Activation of microglia", in fact, is considered as a manifestation of its reactive changes, and therefore it would be more correct to call such a phenomenon as "microglial reactivity". Thus, one of the main signs of microglial reactivity is the cellular mechanisms of phagocytosis activation. The cluster of differentiation 68 (CD68), a lysosomal membrane marker, is considered as a common marker of a highly activated state of phagocytic microglia/macrophages [11].

The available data on CD68-expressing cells are rather contradictory. Despite the obvious positive significance of phagocytosis for tissue such as debris and toxic metabolites elimination, there is evidence that $\mathrm{CD} 68^{+}$microglia are associated with the characteristics of the neurotoxic M1 phenotype [12,13]. However, there are also studies conforming the anti-inflammatory effects of $\mathrm{CD} 68^{+}$cells in animal models $[11,14]$.

Brain CD68-expressing cells are mainly represented by phagocytic microglia, perivascular and meningeal macrophages, macrophages of the choroid plexus, as well as hematogenous macrophages invading brain tissue when it is exposed to various damaging factors. Although we did not perform additional phenotyping of immunopositive cells in our study, the vascular and perivascular expression was statistically ignored. Thus, our attention was directed only to the immunopositive cellular components of the brain parenchyma, not related to the blood-brain barrier structures and meninges. These cellular elements could be theoretically represented by both resident microgliocytes and hematogenous macrophages, which penetrated the tissue due to disruptive changes of blood-brain barrier that is inherent in SAE [15].

The cytoplasmic expression of CD68 has helped to identify the morphological features of the immunopositive cells in CLP-group compared to the control animals, in particular, shifting to a more rounded (amoeboid) shape and an enlarged cell body. Such an amoeboid transformation of microglia is considered as a sign of the resting ramified forms transition to active phagocytic cells. Coupled with the increase in the relative area of the marker expression and the number of immunopositive cells compared to the control, a combination of these morphological differences has resulted in more comprehensive assessment of the phagocytosis activation level in various brain regions in the conditions of SAE. All these indicators of phagocytosis activation were significantly higher in the cortex, white matter, hippocampus and caudate/putamen in the lethal group of animals compared with the control values. In the group of survivors, the significant difference in indicators was characteristic for the same areas, but changes in the cell morphology towards the amoeboid form did not have significant differences compared to the control. The revealed in our study regional-specificity of the increased expression of microglial markers, in particular CD68, in rodents' brain partially coincides with the data of other studies, where other experimental models of systemic inflammation were used [16].

The highest values of the S rel. CD68 expression were found in the white matter and caudate/putamen in the rats died within 24-38 h of the postoperative period given the clinical signs of severe sepsis. High levels of microglial reactivity in the white matter and its detrimental role on myelinated axons and oligodendrocyte precursor cells were previously noted by many authors as critical factor in the pathogenesis of such brain pathologies as multiple sclerosis, Alzheimer's disease, traumatic brain injury, psychiatric pathologies and others $[10,17]$. Michels M. et al. in their studies emphasized the damaging effect of proinflammatory cytokines produced by activated microglia in the hippocampus $[18,19]$.

Our model of experimental sepsis leads to the conclusion that areas such as the white matter and caudate/ putamen (along with the less involved cortex and hippocampus) are probably one of the main brain regions where the most active neuroinflammatory events occur, or there are the sites with more intense brain-immune crosstalk established in the condition of systemic inflammatory challenge.

Higher rates of phagocytosis activation in decompensated animals may indicate predominantly neurotoxic phenotype of immunopositive cells or, on the other hand, represent the activation of phagocytosis only as a natural subsequent outcome of heterogeneous neurotoxicity of a different origin with decompensation of adaptive mechanisms in the tissue. The second option can be indirectly confirmed by the data of our previous study, which has shown early signs of astroglial insufficiency in non-survived animals and the endosomal system activation in reactive astrocytes in survived rats [8]. There is evidence of an active interaction between astroglia and microglia in the brain in conditions of systemic inflammation; however, this issue is still largely ambiguous. Nevertheless, studies of inflammatory influence on the nervous tissue have shown earlier reactive changes in astrocytes, leading to the subsequent reactivation of microglia and manifestation of its neurotoxic properties [15].

Despite the opinion about the predominantly neurotoxic effect of activated microglia in neuropathology, there is growing evidence of an important reparative role of microglia on intracerebral and even systemic homeostasis. Thus, the CLP animal model of severe sepsis has shown the necessity of microglial involvement in reducing the SAE manifestations including signs of systemic inflammation since artificial depletion of the microglial population worsened the consequences of sepsis [19].

Our ultrastructural studies of the animal cortex have shown the active involvement of microglia in the processes of tissue debris phagocytosis, as well as rather early, beginning from the $20^{\text {th }} \mathrm{h}$ of the postoperative period, activation 
of glio-neuronal and glio-vascular communications. The microglial movements to damaged or decayed neurons, as well as the close contacts with them, indicates the active involvement of microglia in the processes of direct intercellular interaction that can be either a favorable or an unfavorable force. In our study, such the glio-neuronal communication was largely typical for animals of the lethal group, where microglia showed the greatest phagocytic activity, based on the parallel immunohistochemical analysis. In survived animals, direct contacts of microglia with neurons were relatively rare by the $48^{\text {th }} \mathrm{h}$. Instead, a tendency towards a more frequent occurrence of microgliocytes loaded with the phagocytosed material in direct contact with the bloodbrain barrier walls was observed in this group, which can be explained by the tissue debris elimination into the vasculature, but not ruling out the brain-systemic signaling activity of microglia.

It should be assumed that this difference in microglial reactivity between the lethal and survived groups is largely explained by the natural reaction of phagocytic glia to more pronounced tissue destructive processes in the non-survived animals, which increased in the dynamics of the postoperative period. However, despite the favorable value of cleansing the tissue from the products of destruction, the excessive intensification of phagocytosis, as described earlier [10,20,21], can also lead to an undesirable direction of pathological processes in the tissue and the aggravation of pathology. Furthermore, given the ability of activated microglia to secrete a number of neurotoxic factors, including reactive oxygen species, glutamate, TNFa and others, the possibility of a wide detrimental signaling effect of phagocytic microglia on the surrounding medium, contributing to an unfavorable scenario of the brain pathology, can not be excluded.

\section{Conclusions}

1. Beginning from the 20th $\mathrm{h}$ after the CLP procedure, the significant (relative to the control) region-specific dynamic increase in the immunohistochemical parameters of phagocytosis activation was observed in the rat brain.

2. All animals of the CLP group, compared with the controls, showed an increase in the parameters of phagocytosis activation in the cortex, subcortical white matter, hippocampus and caudate/putamen, with not significantly different values in the thalamus and the highest indicators in the white matter and caudate/putamen.

3. The greatest increase in parameters of phagocytosis activation in the white matter and caudate/putamen presumably may indicate the localization of the most intense processes of the brain neuroinflammatory response to systemic inflammation.

4. The highest indices of phagocytosis activation in the brain tissue were noted at the $38^{\text {th }} \mathrm{h}$ in the group of the non-survived animals given the decompensated sepsis signs, that most likely indicates a consecutive intensification of the tissue cleansing processes from the decay products under SAE conditions.

5. Ultrastructural signs of microglial reactivity indicated the predominance of close interaction between phagocytic microglia and neurons in the cortex of the non-survived animals and glial-vascular eliminating activity in the brain of the survived animals. That difference may indicate the involvement of phagocytic microglia in neurotoxic mechanisms leading to decompensation of the brain homeostasis during SAE in the non-survived animals.

Prospects for further research. Given the lack of data on glial reactivity in various regions of the brain under conditions of sepsis-associated encephalopathy, it would be appropriate to conduct a detailed morpho-functional analysis of other cell populations, their interaction and roles in the multifactorial dynamic processes of the brain damage and repair in response to systemic inflammation.

\section{Funding}

This study was conducted in the framework of the scientific research work of Zaporizhzhia State Medical University "The morphogenesis of destructive-reparative processes of the brain in the diseases of vascular and toxic-metabolic origin", No. of state registration 0118 U004253 (2018-2022) of the Ministry of Health of Ukraine.

Conflicts of interest: authors have no conflict of interest to declare. Конфмікт інтересів: віАсутній.

НаАійшка Ао реАакції / Received: 02.09.2020

Після Аоопрацювання / Revised: 05.10.2020

Прийнято АО Аруку / Accepted: 13.10.2020

\section{Information about authors:}

Shulyatnikova T. V., MD, PhD, Associate Professor of the Department of Pathological Anatomy and Forensic Medicine, Zaporizhzhia State Medical University, Ukraine.

Shavrin V. O. , MD, PhD, DSc, Professor of the Department of Pathological Anatomy and Forensic Medicine, Zaporizhzhia State Medical University, Ukraine.

\section{Відомості про авторів:}

Шуяятнікова Т. В., канА. меА. наук, Аоцент каф. патологічної анатомії і судової меАицини, Запорізький Аержавний медичний університет, Україна.

Шаврін В. О., А-р меА. наук, професор каф. патологічної анатомії і судової медицини, Запорізький Аержавний медичний університет, Україна.

\section{Сведения об авторах:}

Шуяятникова Т. В., канА. меА. наук, Аоцент каф. патологической анатомии и судебной медицины, Запорожский государственный медицинский университет, Украина. Шаврин В. А. , А-р меА. наук, профессор каф. патологической анатомии и суАебной меАицины, Запорожский

госуАарственный медицинский университет, Украина.

\section{References}

[1] Shuliatnikova, T. V., \& Shavrin, V. O. (2018). Sepsis associated encephalopathy and abdominal sepsis: current state of problem. Art of Medicine, (3), 158-165.

[2] Lamar, C. D., Hurley, R. A., \& Taber, K. H. (2011). Sepsis-Associated Encephalopathy: Review of the Neuropsychiatric Manifestations and Cognitive Outcome. The Journal of Neuropsychiatry and Clinical Neurosciences, 23(3), 237-241. https://doi.org/10.1176//inp.23.3.jnp237

[3] Lannes, N., Eppler, E., Etemad, S., Yotovski, P., \& Filgueira, L. (2017). Microglia at center stage: a comprehensive review about the versatile and unique residential macrophages of the central nervous system. Oncotarget, 8(69), 114393-114413. https://doi.org/10.18632/oncotarget.23106

[4] Li, Q., \& Barres, B. A. (2018). Microglia and macrophages in brain homeostasis and disease. Nature Reviews Immunology, 18(4), 225242. https://doi.org/10.1038/nri.2017.125

[5] Michels, M., Sonai, B., \& Dal-Pizzol, F. (2017). Polarization of microglia and its role in bacterial sepsis. Journal of Neuroimmunology, 303, 90-98. https://doi.org/10.1016/i.jneuroim.2016.12.015 
[6] Michels, M., Danielski, L. G., Dal-Pizzol, F., \& Petronilho, F. (2014). Neuroinflammation: Microglial Activation During Sepsis. Current Neurovascular Research, 11(3), 262-270. https://doi.org/10.2174/156720 2611666140520122744

[7] Hoogland, I. C., Houbolt, C., van Westerloo, D. J., van Gool, W. A., \& van de Beek, D. (2015). Systemic inflammation and microglial activation: systematic review of animal experiments. Journal of Neuroinflammation, 12, Article 114. https://doi.org/10.1186/s12974-015-0332-6

[8] Shuliatnikova, T. V., \& Shavrin, V. O. (2020). Ul'trastrukturnye osobennosti sostoyaniya astroglial'noi endosomal'noi sistemy pri sepsis-assotsiirovannoi entsefalopatii [Ultrastructural features of astroglial endosomal system state in sepsis-associated encephalopathy]. Pathologia, 17(1), 60-67. https://doi.org/10.14739/2310-1237.2020.1.203742 [in Russian].

[9] De Biase, L. M., \& Bonci, A. (2019). Region-Specific Phenotypes of Microglia: The Role of Local Regulatory Cues. The Neuroscientist, 25(4), 314-333. https://doi.org/10.1177/1073858418800996

[10] Lee, J., Hamanaka, G., Lo, E. H., \& Arai, K. (2019). Heterogeneity of microglia and their differential roles in white matter pathology. CNS Neuroscience \& Therapeutics, 25(12), 1290-1298. https://doi. org/10.1111/cns.13266

[11] Yeo, H. G., Hong, J. J., Lee, Y., Yi, K. S., Jeon, C. Y., Park, J., Won, J., Seo, J., Ahn, Y. J., Kim, K., Baek, S. H., Hwang, E. H., Kim, G., Jin, Y. B., Jeong, K. J., Koo, B. S., Kang, P., Lim, K. S., Kim, S. U., Huh, J. W., ... Lee, S. R. (2019). Increased CD68/TGF $\beta$ Co-expressing Microglia/ Macrophages after Transient Middle Cerebral Artery Occlusion in Rhesus Monkeys. Experimental Neurobiology, 28(4), 458-473. https:// doi.org/10.5607/en.2019.28.4.458

[12] Liddelow, S. A., Guttenplan, K. A., Clarke, L. E., Bennett, F. C., Bohlen, C. J., Schirmer, L., Bennett, M. L., Münch, A. E., Chung, W. S., Peterson, T. C., Wilton, D. K., Frouin, A., Napier, B. A., Panicker, N., Kumar, M., Buckwalter, M. S., Rowitch, D. H., Dawson, V. L., Dawson, T. M., Stevens, B., ... Barres, B. A. (2017). Neurotoxic reactive astrocytes are induced by activated microglia. Nature, 541(7638), 481-487. https://doi.org/10.1038/nature21029

[13] O'Neil, S. M., Witcher, K. G., McKim, D. B., \& Godbout, J. P. (2018). Forced turnover of aged microglia induces an intermediate phenotype but does not rebalance CNS environmental cues driving priming to immune challenge. Acta Neuropathologica Communications, 6(1), Article 129. https://doi.org/10.1186/s40478-018-0636-8

[14] Doyle, K. P., Cekanaviciute, E., Mamer, L. E., \& Buckwalter, M. S. (2010). TGF $\beta$ signaling in the brain increases with aging and signals to astrocytes and innate immune cells in the weeks after stroke. Journal of Neuroinflammation, 7, Article 62. https://doi.org/10.1186/17422094-7-62

[15] Shulyatnikova, T., \& Verkhratsky, A. (2020). Astroglia in Sepsis Associated Encephalopathy. Neurochemical Research, 45(1), 83-99. https:// doi.org/10.1007/s11064-019-02743-2

[16] Hoogland, I., Westhoff, D., Engelen-Lee, J. Y., Melief, J., Valls Serón, M., Houben-Weerts, J., Huitinga, I., van Westerloo, D. J., van der Poll, T., van Gool, W. A., \& van de Beek, D. (2018). Microglial Activation After Systemic Stimulation With Lipopolysaccharide and Escherichia coli. Frontiers in Cellular Neuroscience, 12, Article 110. https://doi. org/10.3389/fncel.2018.00110

[17] Li, Y., Zhang, R., Hou, X., Zhang, Y., Ding, F., Li, F., Yao, Y., \& Wang, Y. (2017). Microglia activation triggers oligodendrocyte precursor cells apoptosis via HSP60. Molecular Medicine Reports, 16(1), 603-608. https://doi.org/10.3892/mmr.2017.6673

[18] Michels, M., Abatti, M. R., Ávila, P., Vieira, A., Borges, H., Carvalho Junior, C., Wendhausen, D., Gasparotto, J., Tiefensee Ribeiro, C., Moreira, J., Gelain, D. P., \& Dal-Pizzol, F. (2020). Characterization and modulation of microglial phenotypes in an animal model of severe sepsis. Journal of Cellular and Molecular Medicine, 24(1), 88-97. https:/l doi.org/10.1111/jcmm.14606

[19] Michels, M., Ávila, P., Pescador, B., Vieira, A., Abatti, M., Cucker, L., Borges, H., Goulart, A. I., Junior, C. C., Barichello, T., Quevedo, J., \& Dal-Pizzol, F. (2019). Microglial Cells Depletion Increases Inflammation and Modifies Microglial Phenotypes in an Animal Model of Severe Sepsis. Molecular Neurobiology, 56(11), 7296-7304. https://doi.org/10.1007/ s12035-019-1606-2

[20] Brown, G. C., \& Neher, J. J. (2014). Microglial phagocytosis of live neurons. Nature Reviews Neuroscience, 15(4), 209-216. https://doi. org/10.1038/nrn3710

[21] Fricker, M., Oliva-Martín, M. J., \& Brown, G. C. (2012). Primary phagocytosis of viable neurons by microglia activated with $L P S$ or $A B$ is dependent on calreticulin/LRP phagocytic signalling. Journal of Neuroinflammation, 9, Article 196. https://doi.org/10.1186/1742-2094-9-196 